\title{
PENERAPAN PENGGUNAAN MAGNESOL SEBAGAI ADSORBEN PADA PEMURNIAN BIODIESEL PADA PERUSAHAAN PENGHASIL BIODIESEL
}

\author{
Harimbi Setyawati ${ }^{1}$, Dwi Ana Anggorowati ${ }^{2)}$, Erni Junita Sinaga ${ }^{3)}$ \\ ${ }^{1,2)}$ Program Studi Teknik Kimia, Institut Teknologi Nasional Malang \\ 3) Program Studi Teknik Industri, Institut Teknologi Nasional Malang \\ Email : arimbisetya@yahoo.co.id
}

\begin{abstract}
Abstrak. PT. Alegria Indonesia merupakan salah satu perusahaan penghasil biodiesel yang ada di kota Pasuruan, bahan baku yang digunakan untuk menghasilkan biodiesel adalah biji jarak. Untuk mendapatkan biji jarak perusahaan terebut bekerjasama dengan para petani yang ada di sekitar perusahaan dan Balittas Karangploso Malang. Untuk itu berbagai upaya dilakukan untuk meningkatkan kualitas biodiesel, termasuk pada proses pencucian biodiesel tersebut. Tujuan dari kegiatan pengabdian ini adalah untuk mendapatkan biodiesel dengan kualitas yang baik sesuai dengan standard kelayakan biodiesel di Indonesia dengan proses pencucian menggunakan magnesium silikat (Magnesol). Proses pemurnian dry washing biodiesel menggunakan adsorben magnesium silikat, dapat meningkatkan kemurnian dari biodiesel yang dihasilkan. Penggunaan magnesium silikat yang tepat akan menyerap impurities dengan maksimal, termasuk sisa gliserol, sisa alkohol dan katalis, serta air dan sedimen pada biodiesel.Karakter fisik biodiesel secara umum telah memenuhi standard kelayakan biodiesel di Indonesia yang diatur dalam SNI 04-7182-2006 kecuali beberapa poin yaitu angka setana dan gliserol bebas.Masa aktif magnesium silikat (magnesol) rata-rata adalah sekitar 40-50 menit. Setelah itu disinyalir magnesium silikat (magnesol) telah atau mulai mengalami kejenuhan.
\end{abstract}

Kata kunci: Pemurnian, Biodiesel, Magnesium Silikat

\section{PENDAHULUAN}

Biodiesel didefinisikan sebagai mono-alkyl ester asam lemak yang berasal dari minyak nabati atau lemak hewan. ${ }^{[3]}$ Impurities yang biasanya terkandung pada biodiesel adalah kandungan air, gliserol, sisa katalis dan alkohol. ${ }^{[5,8]}$

Diperlukan proses pemurnian (pencucian) untuk mendapatkan biodiesel yang bebas dari impurities sesuai dengan standard kelayakan biodiesel di Indonesia. Proses pemurnian biodiesel, secara umum dibagi menjadi dua, yaitu wet washing dan dry washing. Wet washing menggunakan air sebagai media pencuci. Sedangkan dry washing merupakan suatu metode pencucian biodiesel dengan menggunakan material adsorben sebagai media pencuci. ${ }^{[6,8]}$

Material adsorben yang digunakan dalam dry washing biasanya adalah magnesium silikat, magnesium alumunium silikat, dll. Dalam hal ini digunakan magnesium silikat sebagai adsorben. Magnesium silikat dapat mengurangi kadar gliserin bebas, gliserin total, kandungan air dan sedimen, kandungan sulfur, debu sulfat dll. ${ }^{[5]}$ Tujuan dari penelitian ini adalah untuk mendapatkan biodiesel dengan kualitas yang baik sesuai dengan standard kelayakan biodiesel di Indonesia dengan proses pencucian menggunakan magnesium silikat(Magnesol) 


\section{METODE PELAKSANAAN}

Proses pembuatan biodiesel membutuhkan tahapan pemurnian salah satunya adalah metode dry washing biodiesel. Material adsorben yang digunakan dalam dry washing biasanya adalah magnesium silikat, alumunium silikat, dll.
Dalam hal ini digunakan magnesium silikat sebagai adsorben. Magnesium silikat dapat mengurangi kadar gliserin bebas, gliserin total, kandungan air dan sedimen, kandungan sulfur, debu sulfat dll.

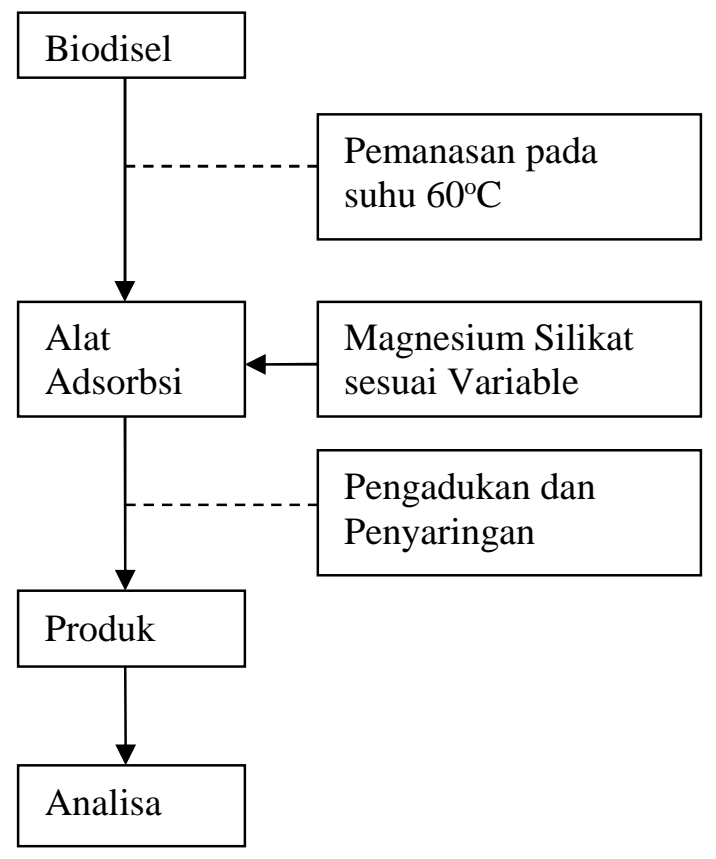

Gambar 1. Bagan Alir Penelitian

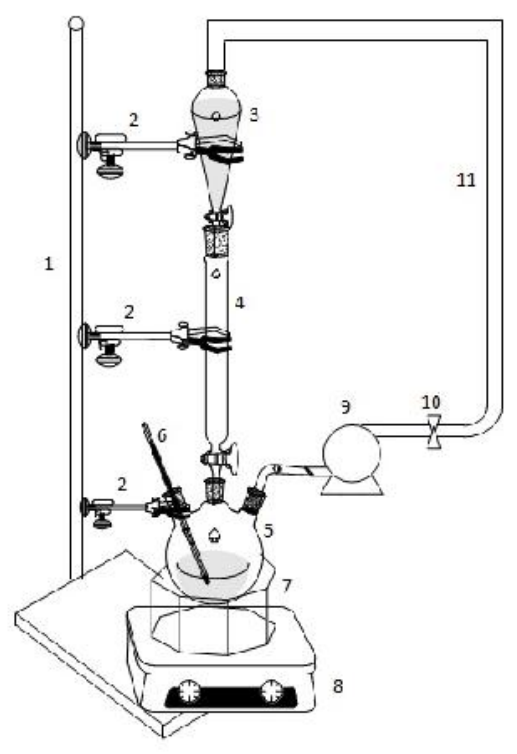

Keterangan Gambar :

1. Tiang statif

2. Klem tunggal

3. Corong pemisah

4. Kolom kaca adsorben

- Tinggi kolom $50 \mathrm{~cm}$

- Diameter kolom 5,8 cm

5. Labu leher tiga

6. Thermometer

7. Bak penampung media pemanas

8. Hot plate

9. Pump

10. Valve

11. Selang

Gambar 2. Sketsa alat adsorbsi 


\section{Cara Kerja Alat:}

Bahan baku berupa biodiesel diletakkan dalam bak penampung. Sejumlah magnesium silikat (magnesol) telah diletakkan pada tabung adsorben. Tabung adsorben ini telah dilengkapi penyaring, sehingga diharapkan impurities tidak dapat lolos. Menyalakan pompa sehingga biodiesel akan melewati pipa inlet, dan mengalir melalui rangkaian pipa yang ada. Dimana rangkaian pipa akan berakhir pada tabung adsorben. Sebelum mencapai tabung adsorben diberikan sebuah alat tambahan berupa tabung penahan. Tabung ini berfungsi untuk menahan aliran yang terlalu besar, sehingga besaran aliran dapat disesuaikan kembali. Proses adsorbsi akan terjadi pada tabung adsorben, dan hasil atau produk akan dialirkan kembali menuju bak penampung produk untuk dijadikan feed kembali. Setelah waktu sesuai dengan variabel, maka valve pada aliran feed ditutup, dan membuka valve pada bak penampung produk, dan akan dihasilkan produk berupa biodiesel yang telah dimurnikan. Langkah ini diulang sesuai dengan variabel

\section{HASIL DAN PEMBAHASAN}

Biodiesel ini merupakan biodiesel kotor, atau biodiesel yang masih mengandung impurities didalamnya. Dan berikut kami tampilkan hasil uji analisa pendahuluan terhadap biodiesel:

Tabel 1. Hasil uji analisa sampel biodiesel kotor

\begin{tabular}{|l|l|}
\hline Parameter & Nilai \\
\hline Densitas $\left(\mathrm{gr} / \mathrm{cm}^{3}\right)$ & 0,895 \\
\hline Gliserol Bebas (\% massa) & 0,0251 \\
\hline Angka Setana & 40 \\
\hline Titik Nyala $\left({ }^{\circ} \mathrm{C}\right)$ & 84 \\
\hline
\end{tabular}

Dari data diatas didapatkan hasil uji analisa terhadap biodiesel dengan beberapa karakteristik, dimana hasil dari uji tersebut biodiesel dianggap tidak layak digunakan karena tidak memenuhi standard kelayakan biodiesel di Indonesia yang diatur dalam SNI 04-7182-2006.

\section{Hasil Uji Pemurnian Biodiesel}

Uji analisa yang dilakukan melalui beberapa tahapan, sebagai berikut:

\section{Densitas}

Dari uji analisa sampel tentang densitas sesuai dengan standard kelayakan biodiesel di Indonesia, berdasar pada SNI 04-71822006, didapatkan hasil sebagai berikut:

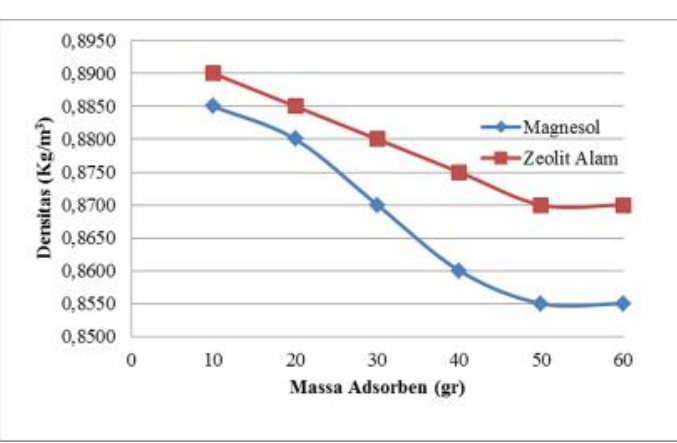

Grafik 1. Pengaruh massa adsorben terhadap densitas

Hasil uji analisa pendahuluan didapatkan data densitas sebesar 0,895. Sedangkan hasil analisa terhadap hasil penelitian menunjukkan penurunan, sebanding dengan massa dari adsorben yang digunakan, dimana hasilnya telah memenuhi standard kelayakan biodiesel di Indonesia, yaitu berada pada kisaran 0,85-0,89 $\mathrm{gr} / \mathrm{cm} 3$. Hal ini dapat terjadi dikarenakan proses adsorbsi yang dilakukan oleh magnesium silikat (magnesol) dan zeolit alam berjalan dengan baik, sehingga kandungan impurities dalam sampel semakin kecil. Pernyataan tersebut sesuai dengan teori yang menyatakan bahwa proses adsorbsi dipengaruhi oleh beberapa faktor, salah satunya adalah massa adsorben.

Dengan menggunakan massa magnesol dan zeolit alam sebesar 10-60 gr, dapat menyebabkan nilai dari densitas turun. Untuk magnesol persentase penurunannya mencapai $2,79 \%$, sedangkan untuk zeolit alam persentase penurunannya mencapai $1,67 \%$. Dari data analisa hasil penelitian didapatkan massa optimum adsorben sebesar 50 gr. Massa optimum ini tidak mengarah pada nilai densitas biodiesel murni, dimana sebaiknya massa optimum adsorben ini mengarah pada densitas biodiesel murni (B100) dengan nilai densitas $0,880 \mathrm{gr} / \mathrm{cm} 3$, sehingga didapatkan massa optimum pada magnesium silikat (magnesol) 
sebesar 20 gr, dan zeolit alam sebesar 30 gr. Namun hal ini menjadi tidak terlalu berarti karena secara umum sampel biodiesel telah sesuai dengan standar kelayakan biodiesel yang ada di indonesia, yaitu $0,850-0,890 \mathrm{~kg} / \mathrm{m} 3$. Dengan demikian ditinjau dari segi nilai densitas, maka sampel biodiesel dapat dikatakan layak digunakan.

\section{Gliserol Bebas}

Dari uji analisa sampel sesuai dengan standard kelayakan biodiesel di Indonesia, berdasar pada SNI 04-7182-2006, didapatkan hasil sebagai berikut:

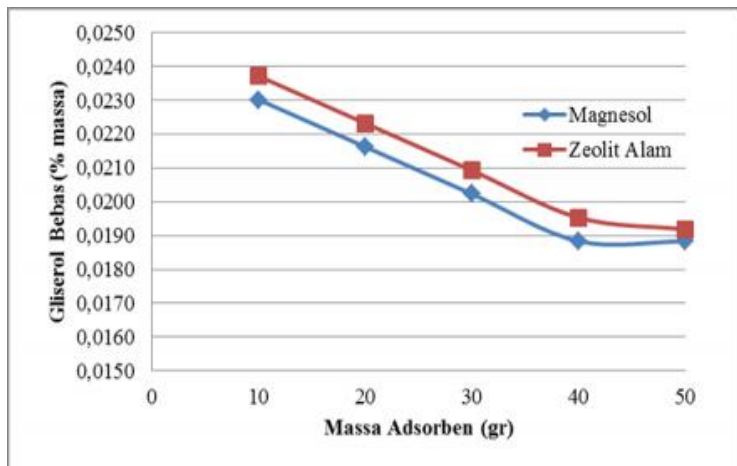

Grafik 2. Pengaruh massa adsorben terhadap gliserol bebas

Hasil uji analisa pendahuluan didapatkan data kandungan gliserol bebas sebesar 0,0251\% massa. Sedangkan hasil analisa terhadap hasil penelitian menunjukkan penurunan, sebanding dengan massa dari adsorben yang digunakan, dimana hasilnya kurang dari $0,02 \%$ massa. Nilai ini menunjukkan adanya penurunan dari kandungan gliserol bebas, hal ini dapat terjadi karena magnesium silikat (magnesol) dan zeolit alam melakukan penyerapan yang maksimal terhadap kandungan impurities yang ada dalam sampel biodiesel, sehingga kandungan gliserol bebas mengalami penurunan. Dengan menggunakan massa magnesol dan zeolit alam sebesar 10-50 gr, maka dapat menurunkan nilai dari gliserol bebas. Untuk magnesol persentase penurunannya mencapai $18,29 \%$, sedangkan untuk zeolit alam persentase penurunannya mencapai $15,79 \%$.

Dari data analisa hasil penelitian, maka sampel biodiesel dapat dikatakan layak digunakan ditinjau dari segi nilai densitas yang terkandung dalam sampel sesuai dengan standard kelayakan biodiesel di Indonesia.

\section{Angka Setana}

Dari uji analisa sampel sesuai dengan standard kelayakan biodiesel di Indonesia, berdasar pada SNI 04-7182-2006, didapatkan hasil sebagai berikut:

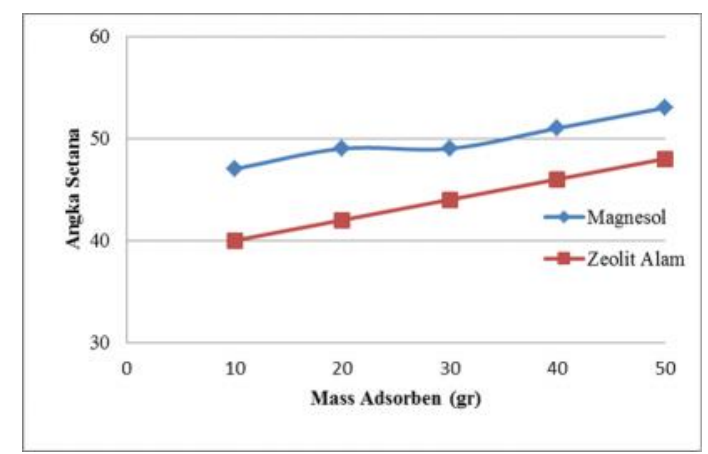

Grafik 3. Pengaruh massa adsorben terhadap angka setana

Hasil uji analisa pendahuluan didapatkan data angka setana sebesar 40. Sedangkan hasil analisa terhadap hasil penelitian menunjukkan peningkatan, sebanding dengan massa dari adsorben yang digunakan, dimana hasilnya lebih dari 40 dan mendekati 51. Nilai ini menunjukkan adanya peningkatan dari angka setana, hal ini dapat terjadi karena magnesium silikat (magnesol) dan zeolit alam melakukan penyerapan yang maksimal terhadap kandungan impurities yang ada dalam sampel biodiesel, sehingga angka setana mengalami peningkatan.

Dengan menggunakan massa magnesium silikat (magnesol) dan zeolit alam sebesar 10-50 gr, dapat menaikkan nilai dari angka setana. Untuk magnesol persentase kenaikan mencapai 24,50 $\%$, sedangkan untuk zeolit alam persentase kenaikan mencapai 10,00\%.

Dari data analisa hasil penelitian maka sampel biodiesel yang diadsorpsi oleh magnesium silikat (magnesol) dapat dinyatakan layak digunakan ditinjau dari segi nilai angka setana yaitu 53 yang terkandung dalam sampel sesuai dengan standard kelayakan biodiesel di Indonesia minimal 51. Namun untuk sampel biodiesel yang diadsorpsi oleh zeolit alam tidak dapat dikatakan layak digunakan ditinjau dari segi nilai angka setana yaitu 48,00 yang terkandung dalam sampel tidak sesuai dengan 
standard kelayakan biodiesel di Indonesia min 51. Ini disebabkan kurangnya temperatur pemanasan pada waktu aktivasi adsorben zeolit alam, sehingga mengakibatkan pori-pori kurang terbuka.

\section{Titik Nyala}

Dari uji analisa sampel sesuai dengan standard kelayakan biodiesel di Indonesia, berdasar pada SNI 04-7182-2006, didapatkan hasil sebagai berikut:

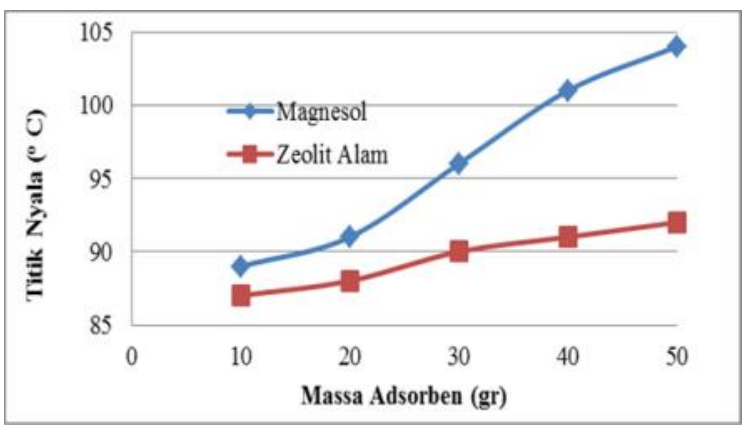

Grafik 4. Pengaruh massa adsorben terhadap titik nyala

Hasil uji analisa pendahuluan didapatkan data titik nyala sebesar 84 . Sedangkan hasil analisa terhadap hasil penelitian menunjukkan peningkatan, sebanding dengan massa dari adsorben yang digunakan, dimana hasilnya telah memenuhi standard kelayakan biodiesel di Indonesia, yaitu lebih dari 100. Nilai ini menunjukkan bahwa sampel biodiesel aman jika disimpan dalam waktu yang lama. Adanya peningkatan dari titik nyala ini dapat terjadi karena magnesium silikat (magnesol) dan zeolit alam melakukan penyerapan yang maksimal terhadap kandungan impurities yang ada dalam sampel biodiesel, sehingga angka setana mengalami peningkatan.

Dengan menggunakan persentase magnesol dan zeolit alam sebesar $1-5 \%$ berat dari biodiesel, dapat menaikkan nilai dari titik nyala. Untuk magnesol persentase kenaikkan mencapai 14,52 $\%$, sedangkan untuk zeolit alam persentase kenaikan mencapai 6,67 \%. Dari data analisa hasil penelitian yang kami lakukan, maka sampel biodiesel yang diadsorbsi oleh magnesium silikat (magnesol) dapat dikatakan layak digunakan ditinjau dari segi nilai titik nyala yaitu $104^{\circ} \mathrm{C}$ yang terkandung dalam sampel sesuai dengan standard kelayakan biodiesel di Indonesia min $100^{\circ} \mathrm{C}$. Namun untuk sampel biodiesel yang diadsorbsi oleh zeolit alam tidak dapat dikatakan layak digunakan ditinjau dari segi nilai titik nyala yaitu $92^{\circ} \mathrm{C}$ yang terkandung dalam sampel tidak sesuai dengan standard kelayakan biodiesel di Indonesia min 100. Ini disebabkan kurangnya temperatur pemanasan pada waktu aktivasi adsorben zeolit alam, sehingga mengakibatkan pori-pori kurang terbuka.

Setelah dilakukan uji analisa pendahuluan dan analisa terhadap hasil penelitian yang dilakukan, maka secara menyeluruh dapat digambarkan melalui tabel sebagai berikut:

Tabel 2. Perbandingan uji analisa pendahuluan dengan hasil penelitian Magnesol.

\begin{tabular}{|llll}
\hline Parameter & $\begin{array}{l}\text { Nilai } \\
\text { Awal }\end{array}$ & $\begin{array}{l}\text { Nilai } \\
\text { Akhir }\end{array}$ & Selisih \\
\hline $\begin{array}{l}\text { Densitas } \\
\left(\mathrm{gr} / \mathrm{cm}^{3}\right)\end{array}$ & 0,895 & 0,8550 & 0,04 \\
\hline $\begin{array}{l}\text { Gliserol Bebas } \\
(\% \text { massa })\end{array}$ & 0,0251 & 0,0188 & 0.0063 \\
\hline Angka Setana & 40 & 53 & -13 \\
\hline Titik Nyala $\left({ }^{\circ} \mathrm{C}\right)$ & 84 & 104 & -20 \\
\hline
\end{tabular}

Data diatas menunjukkan bahwa magnesium silikat (magnesol), layak digunakan untuk proses adsorbsi dalam proses pemurnian biodiesel.

Tabel 3. Perbandingan uji analisa pendahuluan dengan hasil penelitian Zeolit Alam

\begin{tabular}{|lccc}
\hline Parameter & $\begin{array}{c}\text { Nilai } \\
\text { Awal }\end{array}$ & $\begin{array}{l}\text { Nilai } \\
\text { Akhir }\end{array}$ & Selisih \\
\hline Densitas $\left(\mathrm{gr} / \mathrm{cm}^{3}\right)$ & 0,895 & 0,870 & 0,025 \\
\hline $\begin{array}{l}\text { Gliserol Bebas } \\
(\% \text { massa })\end{array}$ & 0,0251 & 0,0192 & 0,0059 \\
\hline Angka Setana & 40 & 48 & -8 \\
\hline Titik Nyala $\left({ }^{\circ} \mathrm{C}\right)$ & 84 & 92 & -8 \\
\hline
\end{tabular}

Data diatas menunjukkan bahwa Zeolit Alam, layak digunakan untuk proses adsorbsi dalam proses pemurnian biodiesel. 


\section{KESIMPULAN}

1. Proses pemurnian dry washing biodiesel menggunakan adsorben magnesium silikat dan zeolit alam, dapat meningkatkan kemurnian dari biodiesel yang dihasilkan. Penggunaan magnesium silikat dan zeolit alam yang tepat akan menyerap impurities dengan maksimal, termasuk sisa gliserol, sisa alkohol dan katalis, serta air dan sedimen pada biodiesel.

2. Untuk karakter fisik biodiesel dengan menggunakan adsorben magnesium silikat (magnesol) dan zeolit alam secara umum telah memenuhi standard kelayakan biodiesel di Indonesia yang diatur dalam SNI 04-7182-2006, kecuali beberapa poin yaitu angka setana dan titik nyala pada adsorben zeolit alam.

3. Sesuai dengan teori semakin besar massa adsorben makan semakin baik kualitas biodieselnya.

4. Pada hasil analisa yang kami dapatkan terdapat perbedaan hasil analisa antara ke dua jenis adsorben yang digunakan. Dimana hasil analisa dengan menggunakan adsorben magnesol lebih baik dari pada zeolit alam.

5. Massa optimum adsorben didapatkan sebesar 50 gr.

\section{DAFTAR PUSTAKA}

[1]. Affandi F dan Hadisi H., 2011 "Pengaruh Metode Aktivasi Zeolit Alam Sebagai Bahan Penurun Temperatur Campuran Beraspal Hangat." Pusat Litbang Jalan dan Jembatan

[2]. Asip F., Mardhiah R,. dan Husna., 2008 "Uji Efektifitas Cangkang Telur Dalam Mengadsorpsi Ion $\mathrm{Fe}$ Dengan Proses Batch.” Jurnal Teknik Kimia Universitas Sriwijaya No. 2 Vol. 15
[3]. Bertram, B., Abrams C., and Cooke, B.S., 2012 "Purification Of Biodiesel With Adsorbent Matrials." The Dalas Group Inc Paten No. US 7,635,398 B2

[4]. Braz J, 2011 "Dry Washing In Biodiesel Purification." Sociendade Brasileira de Quimica Chem. Soc Vol.22 No. 3,558563

[5]. Fitriyantini Z, 2009. "Adsorpsi Karotenoid Dari Metil Ester Minyak Sawit Dengan Menggunakan Adsorben Atapulgit Dan Magnesium Silikat Sintetik." Skripsi Teknologi Industri Pertanian Bogor

[6]. Hartono R., Listiadi A.P., dan Bayupramana I.M., 2013 "Intensifikasi Biodiesel Dari Minyak Jelantah Dengan Metode Interesterifikasi Dan Pemurnian Dry Washing." Jurnal Teknologi Pengolahan Limbah Vol. 16 ISSN 14109565

[7]. Haryati K., Rahmawati D.E., dan Sari I.H., 2009 "Potensi Betonit Sebagai Penjernihan Minyak Goreng Beka." Jurnal Teknik Kimia Universitas Diponegoro

[8]. Herdiani I.A, 2009 "Aplikasi Adsorben dalam Proses Pemurnian Biodiesel Jarak Pagar (Jatropha curcas L.) Menggunakan Metode Kolom." Skripsi Teknologi Industri Pertanian Bogor

[9]. Jatyaraga B.A dan Atmadja L.K., 2013 "Pengaruh Massa Magnesium Silikat (Magnesol) Dan Waktu Operasi." Seminar Hasil Penelitian ITN Malang

[10]. Khaidir., 2011 "Modifikasi Zeolit Alam Sebagai Material Molecular

[11]. Sieve Dan Aplikasinya Pada Proses Dehidrasi Bioetanol." Tesis Teknologi Industri Pertanian Bogor 